\title{
Attention deficit hyperactivity disorder is an independent risk factor for lower resilience in adolescents: a pilot study
}

\author{
Transtorno de déficit de atenção com hiperatividade é fator de risco indepen- \\ dente para menor resiliência em adolescentes: estudo piloto
}

Maria Angélica Regalla, Priscilla Guilherme, Pablo Aguilera, Maria Antonia Serra-Pinheiro, Paulo Mattos*

\begin{abstract}
Objective: Attention deficit hyperactivity disorder (ADHD) is associated with impaired daily functioning in a wide range of domains. Resilience, the ability to overcome and recover from challenges, has been scarcely investigated in ADHD and could potentially provide novel strategies for treatment. However, since ADHD is often comorbid with other clinical conditions, it is necessary to better understand if it impairs resilience levels when controlled for other variables. This pilot study is the first to investigate the correlation between quantitative measures of resilience and ADHD using strict diagnostic criteria by controlling this correlation for comorbid conditions.

Methods: Twelve adolescents diagnosed with ADHD via semi-structured interview using Diagnostic and Statistical Manual of Mental Disorders, 4th edition (DSM-IV) were compared to 12 adolescents exhibiting typical development, regarding resilience, in an analysis controlled for anxiety and depression levels, socioeconomic status, and intelligence quotient (IQ).

Results: The ADHD group was less resilient than the control group ( $p<0.01)$. Importantly, resilience in the ADHD group was not correlated with depression or anxiety, age, intelligence level, and socioeconomic status.

Conclusions: ADHD seems to be associated with lower resilience, which cannot be explained by depression, anxiety, intelligence level, age, or socioeconomic status.
\end{abstract}

Keywords: Attention deficit hyperactivity disorder, resilience, adolescents.

\section{Resumo}

Objetivo: $O$ transtorno de déficit de atenção com hiperatividade (TDAH) se associa a comprometimento funcional em diferentes domínios. Resiliência, o modo como indivíduos enfrentam e superam dificuldades, não foi investigada de modo suficiente no TDAH e poderia sugerir potenciais novas estratégias terapêuticas. Entretanto, sendo o TDAH frequentemente comórbido com outras condições clinicas, é necessário entender se ele compromete a resiliência de modo independente de outras variáveis. Este estudo piloto é o primeiro a investigar a correlação entre medidas quantitativas de resiliência e TDAH diagnosticado de modo estrito controlando-a por variáveis clínicas.

Método: Os níveis de resiliência de 12 adolescentes diagnosticados com TDAH de acordo com os critérios do sistema Manual Diagnóstico e Estatístico de Transtornos Mentais, $4^{a}$ edição (DSM-IV) através de entrevista semiestruturada foram comparados aos de 12 adolescentes com desenvolvimento típico, em uma análise controlada por níveis de ansiedade e depressão, status socioeconômico e inteligência.

Resultados: $\mathrm{O}$ grupo TDAH apresentou menor resiliência do que o grupo controle $(p<0,01)$. Não houve correlação entre resiliência e depressão ou ansiedade, idade, inteligência ou nível socioeconômico.

Conclusões: TDAH parece estar associado a baixos níveis de resiliência que não podem ser justificados por depressão, ansiedade, inteligência, idade ou condição socioeconômica.

Descritores: Transtorno de déficit de atenção com hiperatividade, resiliência, adolescentes.

\footnotetext{
* Instituto de Psiquiatria (IPUB), Universidade Federal do Rio de Janeiro (UFRJ), Rio de Janeiro, RJ, Brazil.

Financial support: none.

Submitted Mar 07 2015, accepted for publication Jun 022015.

Conflicts of interest: Maria Antonia Serra-Pinheiro has served as consultant and has received travel awards to participate in scientific meetings from Shire; and has received travel awards to participate in scientific meetings from Janssen-Cilag and Novartis. Paulo Mattos has been on the speakers bureau, has acted as consultant, and has received travel awards to participate in scientific meetings from Eli-Lilly, Janssen-Cilag, and Novartis. The other authors declare no conflicts of interest concerning the publication of this article.

Suggested citation: Regalla MA, Guilherme P, Aguilera P, Serra-Pinheiro MA, Mattos P. Attention deficit hyperactivity disorder is an independent risk factor for lower resilience in adolescents: a pilot study. Trends Psychiatry Psychother. 2015;37(3):157-160. http://dx.doi.org/10.1590/2237-6089-2015-0010
} 


\section{Introduction}

Attention deficit hyperactivity disorder (ADHD) affects approximately $5 \%$ of children and adolescents worldwide, ${ }^{1}$ being associated with impairment in a wide range of daily activities. Studies on the long-term impact of ADHD show a myriad of outcomes: approximately $20 \%$ of adolescents with ADHD function well in various aspects of their lives, $60 \%$ exhibit intermediate results, and $20 \%$ function poorly in social, educational, and emotional situations. ${ }^{2}$

Academic impairment is one of the most documented areas and a frequent reason for referral. In accordance with what has been demonstrated in different cultural and socioeconomic samples, our group has shown that Brazilian children and adolescents with ADHD from a non-clinical sample exhibited worse academic performance compared to control individuals from the same school settings, despite having similar intelligence levels and rates of comorbid learning disabilities. ${ }^{3,4}$ In another non-clinical sample with low socioeconomic status $^{5}$ we found that inattention was associated with school failure, whereas hyperactivity-impulsivity (H/I) symptoms were not when controlled for inattention. Several studies have investigated the neuropsychological aspects of ADHD that could be associated with impaired functioning. Biederman et al. ${ }^{6}$ suggested that executive function deficits (EFDs) were associated with impaired academic functioning. In a meta-analytical review on the relationship between EFDs and ADHD, Willcutt et al. ${ }^{7}$ found that ADHD individuals with no EFDs were less academically impaired than those with such deficits.

Resilience is defined as the ability to overcome adversity and become stronger - a process of resistance and growth following a crisis or challenge. ${ }^{8}$ Studies on resilience in ADHD could provide novel strategies for treatment, but, since ADHD is often comorbid with clinical conditions that also impair resilience, it is necessary to better understand how ADHD affects resilience levels. ${ }^{9}$

Few studies have described characteristics of ADHD individuals that may contribute to the development of resilience. Wilmshurst et al. ${ }^{10}$ examined psychological well being, self-concept, and academic performance in ADHD-diagnosed college students and found significant differences compared to a control group. In their study, subjects with ADHD reported significantly more support from parents than control students, who reported significantly more support from friends. Modesto-Lowe et al. ${ }^{11}$ have recently addressed the importance of resilience in ADHD while reviewing parenting practices.

This pilot study aims to assess individual resilience of adolescents with ADHD. We hypothesized that: 1) the ADHD group would be less resilient than the control group; and 2) resilience would be unrelated to each individual's depression and anxiety levels, age, intelligence level, and socioeconomic status.

\section{Methods}

We performed a case-control, cross-sectional analytical study with adolescents between 11 and 17 years old. Our sample consisted of 24 adolescents of both genders: 1) the ADHD group consisted of 12 adolescents under regular treatment at the ADHD outpatient program at Instituto de Psiquiatria who were invited as a convenience sample (selected because of their age range); and 2) the control group consisted of 12 adolescents referred from the pediatric outpatient unit at the Instituto de Puericultura e Pediatria, at the same university; they were invited consecutively during their routine check-up. All adolescents with ADHD met strict Diagnostic and Statistical Manual of Mental Disorders, 4th edition (DSM-IV) criteria in semi-structured interviews (Children's Interview for Psychiatric Syndromes - Parent Version, P-ChIPS) conducted together with their parents. Control group participants were also interviewed using the same method.

The following exclusion criteria were used for the two groups (patients and controls): individuals with estimated IQ lower than 80 (based on WISC-III vocabulary and block design subtests); and individuals with history of epilepsy, pervasive developmental disorders, or psychosis.

All adolescents filled out the following questionnaires and scales: a) resilience scale - a 25 item self-report scale using a 7-point Likert scale, with all items positively phrased and addressing values (friendship, personal achievements, satisfaction with life), independence, selfconfidence, resolution, and ability to adapt to different situations ${ }^{12,13}$; b) a self-report inventory for depression, the Children's Depression Inventory (CDI). ${ }^{14}$

Mothers filled out the following questionnaires and scales: a) socioeconomic level questionnaire (according to criteria from the Brazilian Institute of Geography and Statistics [IBGE]); b) Beck Depression Inventory (BDI); c) State-Trait Anxiety Inventory (STAI) (parent report); d) Brazilian version of the Swanson, Nolan, and Pelham Rating scale IV (SNAP-IV) ${ }^{15}$; and e) Child Anxiety Scale (parent self-report). Both parents filled out the Adult Self-report Scale (ASRS) to assess their own ADHD symptoms. ${ }^{16}$

This study was approved by the Ethics Committee of Instituto de Psiquiatria at the Universidade Federal do Rio de Janeiro, Brazil and all parents/adolescents signed a written consent form. 


\section{Results}

The ADHD group was composed mainly by males (83.3\%), something expected in a clinical sample; gender distribution was more balanced in the control group. Mean age did not differ between ADHD and control groups (mean and standard deviations were $13.0 \pm 1.7$ and $13.5 \pm 1.3$ years of age, respectively). Intelligence quotient (IQ) and socioeconomic status scores were significantly higher in the ADHD group (mean 96.0 vs. 89.2 and 24.0 vs 19.0 , respectively). Individual scores on the resilience scale were higher among control individuals compared to the ADHD group $(p=0.008)$ (Table 1 ). Additionally, $41.7 \%$ of ADHDdiagnosed individuals had lower resilience scores than the standardized cutoff for low resilience (110 as cutoff), whereas all control individuals had scores higher than this value. When resilience scores were controlled for gender, there was no evidence that it affected resilience.

There were no statistically significant correlations between resilience and age, IQ, and socioeconomic status.

None of the participants had stress disorder, an aspect potentially associated with resilience. We did not find significant correlations between individual's resilience and CDI, child anxiety, BDI, STAI, and ASRS scores, even when considering ADHD or control groups separately (Spearman correlation). The results generated by this analysis demonstrated statistically significant correlations between the following parameters: 1) depression symptoms in mothers and anxiety symptoms in children in the ADHD group; 2 ) trait anxiety and depression symptoms in mothers in the ADHD group; 3) depression symptoms and neglect in mothers of the control adolescents; 4) depression symptoms and ASRS (total scores) in mothers of the control adolescents; 5) all of the ASRS scores and trait anxiety in mothers of ADHD patients; and 6) hyperactivity and impulsivity symptoms and neglect in mothers of ADHD patients.

\section{Discussion}

This pilot study investigated potential contributing factors for resilience levels in ADHD-diagnosed adolescents via semi-structured interviews by trained professionals using DSM-IV criteria. It is the first study where the correlation between ADHD symptoms and quantitative measures of resilience is investigated.

Our results show significant differences between control and ADHD adolescents regarding resilience. Despite the small sample size, it should be noted that our results indicated a strong correlation between ADHD and low resilience in adolescence. Although our sample had a majority of male adolescents (as expected for clinical ADHD samples), our results were in accordance with other studies with similar samples, including the only one conducted in Brazil. ${ }^{17}$ In this last study with 1,923 adolescents, there was no difference between genders regarding resilience scores, although some specific items of the scale were higher in females (selfesteem and self-confidence).

Our results suggest that, in addition to previously documented impaired functioning in several neuropsychological functions, ADHD-diagnosed children are also less resilient, an aspect that should be considered when evaluating their overall impairment in daily functioning.

Our findings revealed that control adolescents were more resilient compared to ADHD children, despite having lower IQ and socioeconomic status. ADHD was more significant as a risk factor for low resilience levels in the ADHD group than were IQ and socioeconomic level in the control group. In addition, the ADHD group had higher anxiety scores. However, we did not find correlations between resilience and anxiety levels, depression symptoms (evaluated using CDI scores), socioeconomic status, or IQ, in contrast to previous studies.

Taken together, our results suggest that ADHD may be an independent risk factor for low resilience levels.

Table 1 - Descriptive resilience statistics by gender according to groups

\begin{tabular}{|c|c|c|c|c|c|c|}
\hline \multirow[t]{2}{*}{ Resilience statistics } & \multicolumn{3}{|c|}{$\operatorname{ADHD}(n=12)$} & \multicolumn{3}{|c|}{ Control $(n=12)$} \\
\hline & Entire sample & Male & Female & Entire sample & Male & Female \\
\hline$n$ & 12 & 10 & 2 & 12 & 5 & 7 \\
\hline Mean & 114.3 & 114.8 & 112.0 & 133.8 & 137.4 & 131.3 \\
\hline Standard deviation & 18.7 & 20.7 & 1.4 & 8.9 & 10.0 & 7.7 \\
\hline Minimum & 78.0 & 78.0 & 111.0 & 120.0 & 126.0 & 120.0 \\
\hline Maximum & 149.0 & 149.0 & 113.0 & 151.0 & 151.0 & 142.0 \\
\hline Mann-Whitney test $\mathrm{p}$-value & 0.008 & \multicolumn{2}{|c|}{1.000} & 0.008 & \multicolumn{2}{|c|}{0.343} \\
\hline
\end{tabular}

$\mathrm{ADHD}=$ attention deficit hyperactivity disorder. 
This seems particularly relevant, since both anxiety and depression are highly comorbid with ADHD and are associated with different aspects of impaired daily functioning. ${ }^{18} \mathrm{~A}$ possible limitation of the impact of anxiety and depression is the fact that both aspects were investigated through self-report inventories and not semi-structured interviews.

Mother anxiety and depression levels, considered important contributing factors to behavioral problems in offspring with $A D H D,{ }^{19}$ were not associated with resilience levels for the ADHD group in our study.

Finally, socioeconomic levels, which may vary immensely in underdeveloped and developing countries (like ours), are a potential source of burden, whereas our results show that they did not have an impact on resilience levels in our sample. Intelligence (expressed by IQ values) also did not influence resilience levels.

Potential limitations of this study include the discrepancy between control and ADHD groups regarding gender distribution ( $58.3 \%$ females in the control group, compared to $16.7 \%$ in the ADHD group). Additionally, this is a pilot study and our sample size was small.

In summary, ADHD seems to adversely impact resilience levels in adolescents and should be considered an independent risk factor when taking into account potential confounding factors such as depression, anxiety, IQ, age, or socioeconomic status.

\section{References}

1. Polanczyk G, de Lima MS, Horta BL, Biederman J, Rohde LA. The worldwide prevalence of ADHD: a systematic review and metaregression analysis. Am J Psychiatry. 2007;164:942-8.

2. Biederman J, Mike E, Faraone SV. Normalized functioning in youths with persistent attention-deficit/hyperactivity disorder. J Pediatr. 1998;133:544-51.

3. Pastura GMC, Mattos $\mathrm{P}$, Araujo AP. Academic performance in ADHD when controlled for comorbid learning disorders, family income and parental education in Brazil. J Atten Disord. 2009;12:469-73.

4. Albuquerque $G$, Maia $M$, França $A$ Mattos $P$ Pastura $G$. Processamento da linguagem no Transtorno do Déficit de Atenção e Hiperatividade (TDAH). Delta. 2012;28:245-80.
5. Serra-Pinheiro MA, Mattos $P$, Regalla MA, de Souza I, Paixão C. Inattention, hyperactivity, oppositional-defiant symptoms and school failure. Arq Neuro-Psiquiatr. 2008;66:828-31.

6. Biederman J, Monuteaux MC, Doyle AE, Seedman LJ, Wilens $T E$, Ferrero $F$, et al. Impact of executive function deficits and attention-deficit/hyperactivity disorder on academic outcomes in children. J Consult Clin Psychol.2004;72:757-66.

7. Willcutt EG, Doyle AE, Nigg JT, Faraone SV, Pennington BF. Validity of the executive function theory of attention-deficit/hyperactivity disorder: a meta-analytic review. Biol Psychiatry. 2005;57:1336-46.

8. Walsh F. Strengthening family resilience. New York: Guilford Press; 1998.

9. Regalla MA, Guilherme PR, Serra-Pinheiro MA. Resiliência e transtorno de déficit de atenção/hiperatividade. J Bras Psiquiatr. 2007;56:45-9.

10. Wilmshurst $L$, Peele M, Wilmshurst L. Resilience and well-being in college students with and without a diagnosis of ADHD. J Atten Disord. 2011;15:11-7.

11. Modesto-Lowe V, Chaplin M, Godsay V, Soovajiian V. Parenting teens with attentio-deficit /hyperactivity disorder: challenges and opportunities. Clin Pediatr (Phila). 2014;53:943-8.

12. Wagnild GM, Young HM. Development and psychometric evaluation of Resilience Scale. J Nurs Meas. 1993;1:165-78.

13. Pesce RP, Assis SG, Avanci JQ, Santos NC, Malaquias JV, Carvalhaes R. Adaptação transcultural, confiabilidade e validade da escala de resiliência. Cad Saude Publica. 2005;21:436-48.

14. Saylor CF, Finch AJ Jr, Spirito A, Bennett B. The children's depression inventory: a systematic evaluation of psychometric properties. J Consult Clin Psychol.1984;52:955-67.

15. Mattos $P$, Serra-Pinheiro MA, Rohde LA, Pinto D. Apresentação de uma versão em português para uso no Brasil do instrumento MTA-SNAP-IV de avaliação de sintomas de transtorno do déficit de atenção/hiperatividade e sintomas de transtorno desafiador e de oposição. Rev Psiquiatr Rio Gd Sul. 2006;28:290-7.

16. Mattos $P$, Segenreich $D$, Saboya $E$, Louzã M, Dias G, Romano M. Adaptação transcultural para o português da escala Adult Self-Report Scale para avaliação do transtorno de déficit de atenção/hiperatividade (TDAH) em adultos. Rev Psiquiatr Clin. 2006;33:188-94.

17. Assis $S$, Pesce $R$, Avanci J. Resiliência: enfatizando a proteção dos adolescentes. Porto Alegre: Artmed; 2006.

18. Blackman GL, Ostrander R, Herman KC. Children with ADHD and depression: a multisource, multimethod assessment of clinical, social and academic functioning. J Atten Disord. 2005;8:195207.

19. Modesto-Lowe V, Danforth JS, Brooks D. ADHD: does parenting style matter? Clin Pediatr (Phila). 2008;47:865-72.

\section{Correspondence:}

Maria Angélica Regalla

Instituto de Psiquiatria (IPUB), Universidade Federal do Rio de Janeiro (UFRJ)

Rua Carmem Miranda, 681/203, Jardim Guanabara

21931-080 - Rio de Janeiro, RJ - Brazil

E-mail: angelica.regalla@gmail.com 